\title{
A randomised study on the effects of fish protein supplement on glucose tolerance, lipids and body composition in overweight adults
}

\author{
Linn A. Vikøren ${ }^{1}$, Ottar K. Nygård ${ }^{1,2}$, Einar Lied ${ }^{1}$, Espen Rostrup ${ }^{1,2}$ and Oddrun A. Gudbrandsen ${ }^{1 *}$ \\ ${ }^{1}$ Institute of Medicine, University of Bergen, Haukeland University Hospital, N-5021 Bergen, Norway \\ ${ }^{2}$ Department of Heart Disease, Haukeland University Hospital, Bergen, Norway
}

(Submitted 21 November 2011 - Final revision received 29 February 2012 - Accepted 27 March 2012 - First published online 31 May 2012)

\begin{abstract}
The popularity of high-protein diets for weight reduction is immense. However, the potential benefits from altering the source of dietary protein rather than the amount is scarcely investigated. In the present study, we examined the effects of fish protein supplement on glucose and lipid metabolism in overweight adults. A total of thirty-four overweight adults were randomised to 8 weeks' supplementation with fish protein or placebo tablets (controls). The intake of fish protein supplement was $3 \mathrm{~g} / \mathrm{d}$ for the first 4 weeks and $6 \mathrm{~g} / \mathrm{d}$ for the last 4 weeks. In this study, 8 weeks of fish protein supplementation resulted in lower values of fasting glucose $(P<0 \cdot 05), 2 \mathrm{~h}$ postprandial glucose $(P<0 \cdot 05)$ and glucose-area under the curve (AUC) (five measurements over $2 \mathrm{~h}, P<0.05$ ) after fish protein supplementation compared to controls. Glucose-AUC was decreased after 8 weeks with fish protein supplement compared to baseline $(P<0 \cdot 05)$, concomitant with increased $30 \mathrm{~min}$ and decreased $90 \mathrm{~min}$ and $2 \mathrm{~h}$ insulin C-peptide level $(P<0.05)$, and reduced LDL-cholesterol $(P<0.05)$. Body muscle \% was increased $(P<0.05)$ and body fat \% was reduced $(P<0.05)$ after 4 weeks' supplementation. Physical activity and energy and macronutrients intake did not change during the course of the study. In conclusion, short-term daily supplementation with a low dose of fish protein may have beneficial effects on blood levels of glucose and LDL-cholesterol as well as glucose tolerance and body composition in overweight adults. The long-term effects of fish protein supplementation is of interest in the context of using more fish as a protein source in the diet, and the effects of inclusion of fish in the diet of individuals with low glucose tolerance should be evaluated.
\end{abstract}

Key words: Glucose homeostasis: Insulin: Cholesterol: Body composition

The number of people being overweight and obese is increasing in epidemic proportions, and the accompanying influences on health are many and varied. Overweight and obesity are risk factors for several diseases and disorders, and the most common are insulin resistance, type 2 diabetes mellitus, high blood pressure, dyslipidaemia and $\mathrm{CHD}^{(1)}$.

Insulin resistance contributes to the pathophysiology of type 2 diabetes mellitus, and occurs when normal circulating concentrations of insulin fail to achieve the expected response in target tissues such as the muscle and liver. Accumulation of fat, especially in the abdominal region, is negatively correlated with insulin sensitivity ${ }^{(2)}$, whereas skeletal muscle is considered the major organ responsible for glucose uptake in the body and is therefore an important contributor to glucose homeostasis. Obesity is an independent risk factor for $\mathrm{CVD}^{(3)}$, and obese individuals are predisposed to several cardiovascular risk factors including hypertension, dyslipidaemia and type 2 diabetes mellitus, which may increase the rate of plaque formation ${ }^{(4)}$, and weight reduction is associated with improvements in obesity-related co-morbidities ${ }^{(5)}$.
The composition of the diet, and not only the quantity of intake, may be important for achieving and maintaining weight loss over time, and a modest increase in protein intake combined with a modest reduction in glycaemic index shows positive results ${ }^{(6)}$.

The Norwegian health authorities, like most medical societies, recommend a diet relatively rich in carbohydrate and low in fat to prevent obesity and related diseases ${ }^{(7)}$. However, the public interest in alternative diets is increasing, in particular for diets with high protein and high fat content in relation to carbohydrates (e.g. Atkins and Zone diets). High intake of dietary protein at the expense of carbohydrates increases satiety in the short term, and may thereby reduce the intake of energy ${ }^{(8,9)}$. However, the long-term effects of high-protein diets are unknown and the potential detrimental consequences on insulin resistance, glycaemic control and renal function limit their appeal for improving energy balance $^{(8,9)}$. The potential benefits from altering the source of protein, rather than the amount is scarcely emphasised in studies investigating the metabolic consequences of protein

Abbreviations: AUC, area under the curve; CRP, C-reactive protein; HbA1c, glycated Hb; HOMA-IR, homeostasis model assessment - insulin resistance. 
intake. Varying the protein source may modulate insulin resistance in different manners, and based on studies in both human subjects and rats, the intake of fish proteins is believed to have favourable effects on glucose tolerance and insulin sensitivity ${ }^{(10,11)}$. Proteins from different fish species have also been shown to reduce plasma cholesterol level ${ }^{(12-15)}$ and blood pressure ${ }^{(16)}$ in rats, and the beneficial effects of lean fish intake on circulation levels of cholesterol and TAG have been reported in human subjects ${ }^{(17)}$. Therefore, varying the source of protein rather than the amount may be a safer approach to the treatment of metabolic disorders.

On the basis of the beneficial properties reported from fish protein intake in animal models, we wanted to investigate the health benefits provided by the intake of a fish protein supplement in addition to the regular diet of obese and overweight individuals. To our knowledge, there are no published studies investigating the effects of fish protein supplements on glucose homeostasis, lipid metabolism, blood pressure and body composition in overweight and obese human subjects. The present study tested the hypothesis that supplementation with a low daily dose of fish protein for 8 weeks may beneficially modulate glucose tolerance, blood lipids, blood pressure and body weight in overweight and otherwise healthy adults. The fish protein was administered as tablets because it was important not to interfere with or replace the intake of animal and/or vegetable protein in the subjects' normal diets.

\section{Experimental methods}

\section{Trial design}

This study was conducted as an 8-week, double-blind, randomised, controlled intervention study with tablets containing fish protein or no active ingredients (placebo) as control. The primary outcomes of the present study were changes in glucose homeostasis, lipids, C-reactive protein (CRP), blood pressure, BMI, body weight, fat weight and muscle weight, physical activity and dietary intake of macronutrients (proteins, fats and carbohydrates) and energy during the intervention period.

The study was conducted according to the guidelines laid down in the Declaration of Helsinki and all procedures involving human subjects were approved by the Regional Ethics Committee of Western Norway. Written informed consent was obtained from all subjects.

\section{Subjects}

Participants were recruited through adverts and publicity in a local newspaper in August-September 2010. A total of twenty men and twenty women were included in the study, and each intervention group consisted of ten men and ten women. All participants were free-living. The criteria for inclusion were $\mathrm{BMI} \geq 27 \mathrm{~kg} / \mathrm{m}^{2}$, fasting blood glucose $<7 \mathrm{mmol} / \mathrm{l}$, age 20-70 years, no allergies conflicting with the intake of fish and no medications that affected blood pressure, blood lipids or blood sugar. One female participant in the fish protein group initiated blood pressure-lowering medication during the first 4 weeks of the study period (Amlodipin Actavis, a Ca channel blocker), and it was decided to keep this participant in the study to preserve statistical power, but she was excluded from the analysis of systolic and diastolic blood pressure. All participants were of Norwegian ethnic origin. The participants were not allowed to take any nutritional supplements including fish oil for 4 weeks before the study and during the course of the study, and they were instructed to continue their normal eating and exercising habits during the intervention period, with a maximum of one fishmeal per week during the study. All examinations were conducted at the Department of Heart Disease, Haukeland University Hospital (Bergen, Norway).

\section{Intervention}

The fish protein tablets contained $500 \mathrm{mg}$ of protein from codfish, in addition to $350 \mathrm{mg}$ of stabilisation and filling agents (maltodextrin, microcrystalline cellulose, ascorbic acid and $\alpha$-tocopherol) and sweeteners (fructose and vanilla). The placebo tablets consisted of $850 \mathrm{mg}$ of the same sweeteners, stabilisation and filling agents as the protein tablets. Science in Nutrition Ltd/NuF (Bergen, Norway) produced the fish proteins used in this study. The tablets containing fish protein or placebos were marked A or B by the manufacturer, and participants, researchers and nurses involved in the trial were all blinded. Table 1 shows the amino acid composition of the fish protein supplement used in this study.

The participants consumed six tablets per $\mathrm{d}$ for the first 4 weeks of intervention, providing a total of $3000 \mathrm{mg}$ of fish protein. For the last 4 weeks, the participants consumed twelve tablets per d, corresponding to $6000 \mathrm{mg}$ of fish protein daily. In the study, two or four tablets were consumed preceding each of three main meals, usually breakfast, lunch and dinner to obtain an intake of 3000 or $6000 \mathrm{mg}$ fish protein per $\mathrm{d}$, respectively.

Table 1. Amino acid and taurine content in fish protein supplements

\begin{tabular}{lc}
\hline Amino acid & $\mathrm{g} / \mathrm{kg}$ fish protein \\
\hline Ala & $59 \cdot 3$ \\
Arg & $59 \cdot 9$ \\
Asp & $97 \cdot 4$ \\
Glu & $146 \cdot 8$ \\
Gly & $43 \cdot 0$ \\
His & $21 \cdot 3$ \\
Hydroxyproline & $2 \cdot 5$ \\
Ile & $43 \cdot 6$ \\
Leu & $80 \cdot 7$ \\
Lys & $88 \cdot 2$ \\
Met & $29 \cdot 9$ \\
Phe & $37 \cdot 5$ \\
Pro & $32 \cdot 0$ \\
Ser & $43 \cdot 0$ \\
Taurine & $7 \cdot 2$ \\
Thr & $43 \cdot 6$ \\
Trp & $10 \cdot 1$ \\
Tyr & 34.4 \\
Val & 46.6 \\
\hline
\end{tabular}

* Shown in terms of protein (nitrogen $\times 6 \cdot 25)$. 


\section{Protocol for study visits}

The total study period was 8 weeks, with controls at baseline, 4 weeks and at the end of the study ( 8 weeks). The participants were asked to register their intake of food and drink for $24 \mathrm{~h}$ before each visit (at baseline, 4 weeks and 8 weeks), and they were interviewed about their physical activity at the visits. Examinations were conducted in the morning after an overnight fast and study tablets were not taken that morning. Body weight and body composition were measured using a bioelectrical impedance analysis device (InBody 720; Biospace Company Limited ${ }^{(18,19)}$. The manufacturer's guidelines for use were followed and the participants were weighed wearing light clothing and no shoes or socks. Body height was measured. Blood pressure was measured using the Sciller BP-200 plus (Sciller AG) and a medium-size cuff, after the participant had been lying relaxed for 5 min.

Blood samples were collected at five time points at each examination, i.e. in the fasting state, and 30, 60, 90 and $120 \mathrm{~min}$ after eating a standardised breakfast meal. Blood was collected in BD Vacutainer SST II Advance gel tubes (Becton, Dickinson and Company) for isolation of serum and $\mathrm{K}_{2}$ EDTA Vacuette tubes (Greiner Bio-one) for collection of whole blood samples. Due to repeated sampling, the participants were offered anaesthetic patches $(25 \mathrm{mg}$ lidocain and $25 \mathrm{mg}$ prilocain, EMLA; AstraZeneca).

A standardised breakfast meal was designed to provide a glucose load for testing the glucose tolerance during the intervention. The breakfast consisted of two slices of white bread, $10 \mathrm{~g}$ margarine, two slices of Norvegia cheese and 0.3 litres orange juice, and contained $54 \mathrm{~g}$ carbohydrates, $16 \mathrm{~g}$ fat and $13 \mathrm{~g}$ protein, and gave a total energy intake of $1754 \mathrm{~kJ}$. The macronutrient and energy content was calculated using 'Mat på Data 5.1', which is based on Norwegian data of analysis, calculated values, in addition to some values collected from foreign food tables (edited in 2006 by the Norwegian Socialand Health Department, the Norwegian Food Safety Authority and the University of Oslo, http://matportalen.no/Emner/matpadata).

\section{Analyses of serum and blood samples}

Analysis of blood serum was performed by accredited routine methods at the Laboratory of Clinical Biochemistry and the Hormone Laboratory at Haukeland University Hospital (Bergen, Norway). Glycated Hb (HbA1c) in whole blood was analysed at Bevital AS (www.bevital.no). The postprandial glucose response was calculated as the area under the curve (AUC) for five glucose measurements with $30 \mathrm{~min}$ intervals at each visit, using the trapezoid rule as described by Matthews et $a l{ }^{(20)}$. Insulin sensitivity (homeostasis model assessment - insulin resistance (HOMA-IR)) ${ }^{(21)}$ was calculated from fasting plasma glucose and insulin concentrations as glucose $(\mathrm{mmol} / \mathrm{l}) \times$ insulin $(\mathrm{mU} / \mathrm{l})$ divided by $22 \cdot 5$.

\section{Estimation of energy intake}

Calculations of macronutrient and energy intakes were performed using 'Mat på Data 5.1', based on the reported food and drink intake data from the participants at baseline, after 4 weeks and 8 weeks.

\section{Analysis of amino acid composition in fish protein}

The amino acids in the fish protein were analysed in duplicates by BioLab Analyse/Nofima AS according to the method of Cohen \& Michaud ${ }^{(22)}$. In brief, the samples were hydrolysed with $6 \mathrm{~m}-\mathrm{HCl}$ at $110^{\circ} \mathrm{C}$ for $24 \mathrm{~h}$ followed by derivatisation with 6-aminoquinolyl- $N$-hydroxysuccinimidyl carbamate. The amino acid derivatives were separated by reverse phase HPLC in a Waters 2695 Separation Unit, and read in a Waters 2475 Multi Florescence Detector, with excitation at $250 \mathrm{~nm}$ and emission at $395 \mathrm{~nm}$.

\section{Statistical analyses}

Statistical analyses were conducted using PASW Statistics 19.0 (SPSS, Inc., IBM Company). The Shapiro-Wilks test was used to assess normality. The majority of data were not normally distributed and therefore non-parametric tests were used for all data comparisons. The Mann-Whitney $U$ test was used to compare data between groups. The Wilcoxon signed ranks test for paired samples was used to compare changes within groups over the time course of the study. Data are presented as medians with interquartile ranges. $P$ values $<0.05$ were considered statistically significant.

\section{Results}

\section{Participant characteristics and flow}

A total of twenty men and twenty women were included in the study, and the participants were randomly assigned to fish protein or placebo groups with ten women and ten men in each group. Overall, sixteen participants in the placebo group and eighteen participants in the fish protein group completed the study. Here, five of six dropouts were men; the highest dropout was from the placebo group where four participants (three men) withdrew; two participants (both men) withdrew from the protein group. Table 2 displays the baseline characteristics of the study groups. No statistically significant differences were found between the treatment groups for age or BMI.

\section{Energy and macronutrient intake}

Participants registered their intake of food and drink for $24 \mathrm{~h}$ at baseline and after 4 and 8 weeks. No statistically significant changes were seen in the macronutrient and energy intake during the course of the study, and also no differences between the treatment groups were found at any time points (Table 3).

\section{Physical activity}

The participants were interviewed about their exercising habits, and only two women in the control group reported moderate changes in their exercising behaviour during the 
Table 2. Baseline characteristics*

(Median values and interquartile ranges)

\begin{tabular}{|c|c|c|c|c|}
\hline & Median & Interquartile range & Median & Interquartile range \\
\hline Men/women & \multicolumn{2}{|c|}{$7 / 9$} & \multicolumn{2}{|c|}{$8 / 10$} \\
\hline Age (years) & 45.5 & $37 \cdot 6-53 \cdot 8$ & $41 \cdot 3$ & $36.5-51.9$ \\
\hline BMI $\left(\mathrm{kg} / \mathrm{m}^{2}\right)$ & $34 \cdot 7$ & $31 \cdot 1-36 \cdot 9$ & $33 \cdot 6$ & $31 \cdot 5-35 \cdot 8$ \\
\hline
\end{tabular}

* No significant differences $(P<0.05)$ were found between the groups.

study period. Based on the interviews, there were no significant changes in physical activity in either group (data not shown).

\section{Glucose homeostasis}

The participants underwent glucose tolerance tests at each of the three examinations (at baseline, midway ( 4 weeks) and at the end of the study ( 8 weeks) to evaluate responses of intervention on glucose homeostasis. Comparisons of fasting levels of glucose, insulin and insulin C-peptide, as well as the calculated value of HOMA-IR, revealed that there were no differences between the fish protein group and the placebo group at baseline and after 4 weeks (Table 4). At the end of the study, the fasting glucose level was significantly lower in the fish protein group when compared to placebo, whereas no differences were seen in fasting insulin, fasting insulin C-peptide and HOMA-IR at this time point. No changes were seen in HOMA-IR or fasting levels of glucose, insulin or insulin C-peptide within the groups over time.

The glucose, insulin and insulin C-peptide levels $2 \mathrm{~h}$ after the glucose tolerance test ( $2 \mathrm{~h}$ glucose) were not significantly different between the groups at baseline and after 4 weeks. After 8 weeks, the $2 \mathrm{~h}$ glucose level was significantly lower in the fish protein group compared to placebo, but no differences between the groups were seen regarding $2 \mathrm{~h}$ insulin and $2 \mathrm{~h}$ insulin $\mathrm{C}$-peptide at this time point. The $2 \mathrm{~h}$ insulin C-peptide level was significantly decreased after 8 weeks relative to baseline in the fish protein group. Serum levels of both insulin and insulin C-peptide were significantly increased after $30 \mathrm{~min}$ and significantly reduced $90 \mathrm{~min}$ after intake of the standardised breakfast in the fish protein group after 8 weeks when compared to baseline, whereas no changes were seen in insulin and insulin C-peptide levels after $60 \mathrm{~min}$. Besides, no changes were seen in insulin and insulin C-peptide levels after 30, 60 or $90 \mathrm{~min}$ in the placebo group from baseline to 8 weeks. The $2 \mathrm{~h}$ glucose level decreased significantly from baseline to 8 weeks in the placebo group, whereas $2 \mathrm{~h}$ insulin and insulin C-peptide levels were unchanged.

The AUC for five glucose measurements was compared between the experimental groups, and the levels were similar at baseline and were significantly lower in the fish protein group when compared to controls after 8 weeks. The AUC within-group change was not altered in the placebo group over time. In the protein group, AUC was significantly decreased after 4 weeks, and this effect persisted to 8 weeks when compared to baseline.

HbA1c was analysed at baseline and at the end of the study. The HbA1c level was significantly increased after 8 weeks of fish protein supplementation, whereas no differences were seen between the fish protein and placebo groups at these time points. No significant change in HbA1c was observed in the placebo group.

CRP and alanine transaminase were not significantly different between groups at any time point and no significant changes were found within groups over time.

\section{Serum lipids}

Serum levels of total cholesterol, HDL-cholesterol and TAG were not significantly different between groups at any of the three time points and no statistically significant changes were seen during the course of the study (Table 5). The LDL-cholesterol level was significantly reduced in the fish protein group at the end of the study compared to baseline whereas no change was seen in the placebo group. A significant increase in the HDL:LDL ratio was seen in the fish protein group at the end of the study when compared to baseline. Also, no change was seen in serum bile acids over time or between groups at any time points.

\section{Blood pressure}

No significant differences were seen for systolic or diastolic blood pressure between the fish protein group and controls at any time points (Table 6). Also, no changes were seen in systolic or diastolic blood pressure over time for the protein group. A borderline reduction in diastolic blood pressure was seen after 8 weeks in the placebo group $(P=0.049)$ when compared to baseline.

\section{Body weight and body composition}

Body weight and body composition, shown as percentages of fat and muscle relative to body weight, did not differ significantly between groups at any time points (Table 7). Body weight and percentage of muscle were significantly increased during the first 4 weeks of the study in the fish protein group, concomitant with a significant reduction of percentage of body fat. 


\section{Discussion}

In this randomised, double-blinded, placebo-controlled intervention study on overweight adults, we found beneficial effects of short-term supplementation of low-dose daily fish protein supplementation on glucose tolerance, serum LDLcholesterol and body composition, without significant changes in the energy and macronutrient intake or physical activity. To our knowledge, this is the first time that the health effects of a fish protein supplement have been reported in humans.

The most important finding regarding glucose homeostasis was the beneficial effect of fish protein supplement on glucose tolerance. The postprandial glucose tolerance, calculated as AUC for five glucose measurements (every $30 \mathrm{~min}$ for 120 min) was significantly improved after 8 weeks, and fasting glucose, $2 \mathrm{~h}$ glucose and AUC were lower in the fish protein group when compared to controls. This is in agreement with reports in rats fed cod protein ${ }^{(10)}$ and insulin-resistant subjects eating cod fillets ${ }^{(11)}$ showing increased glucose tolerance. The improved glucose tolerance may be due to factors such as increased early insulin secretion from the pancreas or increased insulin sensitivity, as both insulin and insulin C-peptide serum levels were increased 30 min postprandially after 8 weeks when compared to baseline. However, the insulin serum level was reduced after $90 \mathrm{~min}$ and was unchanged in the fasting state and $2 \mathrm{~h}$ postprandially after fish protein supplementation. Insulin C-peptide is a by-product of insulin secretion and is secreted in equimolar quantities from the pancreas together with insulin, and is catabolised at a slower rate compared to insulin and the serum insulin C-peptide level may therefore be used to estimate insulin secretion ${ }^{(23)}$.

Although no change was seen in the fasting level of insulin C-peptide over time, a significant reduction in $90 \mathrm{~min}$ and $2 \mathrm{~h}$ postprandial insulin C-peptide levels were observed after 8 weeks in the fish protein group. Thus, our findings suggest that fish protein supplementation may improve glucose tolerance through increased early insulin secretion after a meal.

The HOMA-IR model was used to evaluate insulin sensitivity in the present study, estimated by mathematical modelling of fasting glucose and fasting insulin concentrations $^{(21)}$. Improved insulin sensitivity could explain the improved glucose tolerance; however, no significant changes were seen in the HOMA-IR index in the fish protein group. The HOMA-IR index assumes that hepatic and peripheral insulin sensitivity contributes to the same extent to whole-body insulin sensitivity. However, the hepatic and peripheral insulin sensitivity can differ considerably in the same individual and this raises concerns about the use of the HOMA-IR index as a measure of in vivo insulin sensitivity ${ }^{(24)}$. Codfish proteins are reported to primarily improve peripheral insulin sensitivity in animals by enhancing insulin-stimulated glucose dispo$\mathrm{sal}^{(10)}$, and in line with this the observed improvement in glucose tolerance in the protein group may be associated with improved peripheral insulin sensitivity, meaning that one of the assumptions of the HOMA-IR model might be violated and it may be unsuitable for use in this situation. The unchanged fasting glucose and the increased HbA1c observed in the protein group after 8 weeks support the suggestion that 
Table 4. Glucose homeostasis variables and C-reactive protein (CRP) (Median values and interquartile ranges)

\begin{tabular}{|c|c|c|c|c|c|c|c|c|c|c|c|c|}
\hline & \multicolumn{4}{|c|}{ Baseline } & \multicolumn{4}{|c|}{4 weeks } & \multicolumn{4}{|c|}{8 weeks } \\
\hline & \multicolumn{2}{|c|}{ Placeboł } & \multicolumn{2}{|c|}{ Fish protein $\ddagger$} & \multicolumn{2}{|c|}{ Placeboł } & \multicolumn{2}{|c|}{ Fish protein $\ddagger$} & \multicolumn{2}{|c|}{ Placebo $\ddagger$} & \multicolumn{2}{|c|}{ Fish protein $\ddagger$} \\
\hline & Median & $\begin{array}{l}\text { Interquartile } \\
\text { range }\end{array}$ & Median & $\begin{array}{l}\text { Interquartile } \\
\text { range }\end{array}$ & Median & $\begin{array}{l}\text { Interquartile } \\
\text { range }\end{array}$ & Median & $\begin{array}{l}\text { Interquartile } \\
\text { range }\end{array}$ & Median & $\begin{array}{l}\text { Interquartile } \\
\text { range }\end{array}$ & Median & $\begin{array}{l}\text { Interquartile } \\
\text { range }\end{array}$ \\
\hline Fasting glucose $(\mathrm{mmol} / \mathrm{l})$ & $5 \cdot 6$ & $5 \cdot 2-5 \cdot 9$ & $5 \cdot 3$ & $4.9-5.5$ & $5 \cdot 6$ & $5 \cdot 1-6 \cdot 1$ & $5 \cdot 3$ & $4.7-5 \cdot 6$ & 5.7 & $5 \cdot 2-6 \cdot 0$ & $5.2 \dagger$ & $4.9-5.6$ \\
\hline $2 \mathrm{~h}$ Glucose $(\mathrm{mmol} / \mathrm{l})$ & $5 \cdot 3$ & $4 \cdot 9-5 \cdot 6$ & 4.9 & $4 \cdot 3-5 \cdot 3$ & 4.9 & $4 \cdot 4-5 \cdot 8$ & 4.7 & $4 \cdot 3-5 \cdot 1$ & $5 \cdot 1^{*}$ & $4 \cdot 7-5 \cdot 5$ & $4.4 \dagger$ & $4 \cdot 2-5 \cdot 0$ \\
\hline $\begin{array}{l}\text { AUC-glucose (mmol// per } \\
\text { min) }\end{array}$ & 740 & $672-814$ & 719 & $600-769$ & 719 & $665-760$ & $647^{*}$ & $583-707$ & 732 & $631-788$ & $645^{*} \dagger$ & $560-680$ \\
\hline $\mathrm{HbA1c}(\%)$ & 5.8 & $5 \cdot 4-6 \cdot 2$ & 5.8 & $5 \cdot 4-6 \cdot 1$ & & ND & & ND & $5 \cdot 7$ & $5 \cdot 4-6 \cdot 3$ & $5 \cdot 9^{\star}$ & $5 \cdot 8-6 \cdot 3$ \\
\hline Fasting insulin (pmol/l) & 73 & $41-102$ & 58 & $37-91$ & 72 & $37-103$ & 49 & $28-88$ & 68 & $50-92$ & 61 & $34-94$ \\
\hline $30 \mathrm{~min}$ insulin $(\mathrm{pmol} / \mathrm{l})$ & 319 & $203-430$ & 249 & $145-338$ & 293 & $185-401$ & 286 & $176-478$ & 367 & $268-439$ & $333^{*}$ & $206-496$ \\
\hline $60 \mathrm{~min}$ insulin $(\mathrm{pmol} / \mathrm{l})$ & 321 & $249-401$ & 233 & $104-440$ & 329 & $157-545$ & 187 & $124-421$ & 343 & $265-424$ & 250 & $127-377$ \\
\hline 90 min insulin $(\mathrm{pmol} / \mathrm{l})$ & 193 & $125-347$ & 148 & $95-296$ & 184 & $114-279$ & 121 & $93-320$ & 217 & $140-278$ & $142^{*}$ & $88-204$ \\
\hline $2 \mathrm{~h}$ insulin (pmol/l) & 155 & $93-245$ & 119 & $74-233$ & 188 & $91-224$ & 106 & $68-118$ & 158 & $107-196$ & 108 & $68-149$ \\
\hline HOMA-IR & $2 \cdot 7$ & $1 \cdot 7-4 \cdot 2$ & $2 \cdot 3$ & $1.4-3.7$ & 2.9 & $1.5-4.1$ & $2 \cdot 1$ & $1 \cdot 0-3 \cdot 7$ & $2 \cdot 8$ & $2 \cdot 1-3 \cdot 6$ & $2 \cdot 4$ & $1 \cdot 1-3 \cdot 8$ \\
\hline $\begin{array}{l}\text { Fasting insulin C-peptide } \\
(\mathrm{nmol} / \mathrm{l})\end{array}$ & 0.94 & $0.68-1.13$ & 0.84 & $0.69-1.08$ & 0.91 & $0 \cdot 70-1 \cdot 16$ & $0 \cdot 70$ & $0 \cdot 62-1 \cdot 16$ & 0.98 & $0 \cdot 83-1 \cdot 16$ & 0.82 & $0 \cdot 65-1 \cdot 13$ \\
\hline $\begin{array}{l}30 \text { min insulin C-peptide } \\
(\mathrm{nmol} / \mathrm{l})\end{array}$ & $2 \cdot 77$ & $2 \cdot 05-3 \cdot 34$ & 2.43 & $1.97-3.31$ & $2 \cdot 41$ & $1.97-3.51$ & $2 \cdot 70$ & $1.97-3.67$ & $2 \cdot 88$ & $2.55-3.38$ & $2 \cdot 74^{\star}$ & $2 \cdot 28-3 \cdot 84$ \\
\hline $\begin{array}{l}60 \text { min insulin C-peptide } \\
(\mathrm{nmol} / \mathrm{l})\end{array}$ & 3.04 & $2.53-3.71$ & $3 \cdot 13$ & $1.61-3.52$ & 2.89 & $2 \cdot 17-3 \cdot 61$ & $2 \cdot 26$ & $1 \cdot 79-3.40$ & 2.85 & $2 \cdot 20-4 \cdot 01$ & 2.99 & $1 \cdot 67-3 \cdot 39$ \\
\hline $\begin{array}{l}90 \text { min insulin C-peptide } \\
(\mathrm{nmol} / \mathrm{l})\end{array}$ & $2 \cdot 38$ & $1 \cdot 88-3 \cdot 64$ & $2 \cdot 35$ & $1 \cdot 55-3 \cdot 18$ & $2 \cdot 17$ & $1.61-3.00$ & 1.95 & $1.48-2.95$ & $2 \cdot 33$ & $1.86-2.92$ & $2 \cdot 07^{\star}$ & $1 \cdot 32-2 \cdot 39$ \\
\hline $\begin{array}{l}2 \mathrm{~h} \text { insulin C-peptide } \\
(\mathrm{nmol} / \mathrm{l})\end{array}$ & $1 \cdot 70$ & $1 \cdot 36-2 \cdot 48$ & $1 \cdot 70$ & $1 \cdot 21-2 \cdot 31$ & 1.77 & $1 \cdot 51-2 \cdot 21$ & $1 \cdot 32$ & $1.09-1.93$ & $1 \cdot 77$ & $1 \cdot 39-2 \cdot 12$ & $1.56^{\star}$ & $1.06-1.97$ \\
\hline CRP (mg/l) & $2 \cdot 0$ & $1.0-3.8$ & 3.5 & $2 \cdot 0-5 \cdot 0$ & $2 \cdot 0$ & $1 \cdot 2-3 \cdot 8$ & 3.0 & $1.0-4.3$ & $2 \cdot 0$ & $1 \cdot 0-2 \cdot 8$ & 3.0 & $1 \cdot 8-6 \cdot 3$ \\
\hline ALT (U/I) & $30 \cdot 0$ & $24.5-45.5$ & $31 \cdot 0$ & $22 \cdot 0-41 \cdot 0$ & & ND & & ND & 32.5 & $20 \cdot 3-41.5$ & 29.5 & $22 \cdot 0-35 \cdot 2$ \\
\hline
\end{tabular}

AUC-glucose, area under the curve for five measurements of glucose; HbA1c, glycated $\mathrm{Hb}$; ND, not determined; HOMA-IR, homeostasis model assessment - insulin resistance; ALT, alanine transaminase. "Median values were significantly different from baseline within the experimental group $(P<0.05)$. The Wilcoxon signed-rank test was used to compare change within groups over time.

tMedian values were significantly different from the placebo group at the same point of time $(P<0.05)$. The Mann-Whitney $U$ test was used to compare groups.

$\ddagger n 16$ in the placebo group and $n 18$ in the fish protein group, except for AUC and 30,60 and 90 min serum levels of insulin and insulin C-peptide where $n 12$ in the placebo group, $n 11$ in the fish protein group. 
Table 5. Serum lipids and bile acids $\uparrow$

(Median values and interquartile ranges; $n 16$ in the placebo group and $n 18$ in the fish protein group)

\begin{tabular}{|c|c|c|c|c|c|c|c|c|c|c|c|c|}
\hline & \multicolumn{4}{|c|}{ Baseline } & \multicolumn{4}{|c|}{4 weeks } & \multicolumn{4}{|c|}{8 weeks } \\
\hline & \multicolumn{2}{|c|}{ Placebo } & \multicolumn{2}{|c|}{ Fish protein } & \multicolumn{2}{|c|}{ Placebo } & \multicolumn{2}{|c|}{ Fish protein } & \multicolumn{2}{|c|}{ Placebo } & \multicolumn{2}{|c|}{ Fish protein } \\
\hline & Median & $\begin{array}{l}\text { Interquartile } \\
\text { range }\end{array}$ & Median & $\begin{array}{l}\text { Interquartile } \\
\text { range }\end{array}$ & Median & $\begin{array}{l}\text { Interquartile } \\
\text { range }\end{array}$ & Median & $\begin{array}{l}\text { Interquartile } \\
\text { range }\end{array}$ & Median & $\begin{array}{l}\text { Interquartile } \\
\text { range }\end{array}$ & Median & $\begin{array}{l}\text { Interquartile } \\
\text { range }\end{array}$ \\
\hline $\begin{array}{l}\text { Total cholesterol } \\
(\mathrm{mmol} / \mathrm{l})\end{array}$ & $5 \cdot 1$ & $4 \cdot 4-6 \cdot 2$ & $5 \cdot 1$ & $4.7-5.7$ & 5.4 & $4.7-5.9$ & $5 \cdot 1$ & $4.6-5.9$ & $5 \cdot 3$ & $4.6-5.9$ & $5 \cdot 1$ & $4 \cdot 7-5 \cdot 8$ \\
\hline $\begin{array}{l}\text { HDL-cholesterol } \\
(\mathrm{mmol} / \mathrm{l})\end{array}$ & $1 \cdot 1$ & $1 \cdot 0-1 \cdot 3$ & $1 \cdot 2$ & $1 \cdot 0-1.4$ & $1 \cdot 1$ & $1 \cdot 0-1 \cdot 3$ & $1 \cdot 2$ & $1.0-1.5$ & $1 \cdot 2$ & $1 \cdot 0-1 \cdot 3$ & $1 \cdot 2$ & $1.0-1.5$ \\
\hline $\begin{array}{l}\text { LDL-cholesterol } \\
\qquad(\mathrm{mmol} / \mathrm{l})\end{array}$ & $3 \cdot 6$ & $2 \cdot 6-4 \cdot 3$ & $3 \cdot 3$ & $3 \cdot 1-3 \cdot 9$ & $3 \cdot 8$ & $2 \cdot 9-4 \cdot 0$ & $3 \cdot 3$ & $3.0-3.9$ & $3 \cdot 7$ & $3 \cdot 0-4 \cdot 3$ & $3 \cdot 2^{\star}$ & $3.0-3.5$ \\
\hline $\begin{array}{l}\text { HDL:LDL-cholesterol } \\
\quad \text { ratio }\end{array}$ & 0.32 & $0.26-0.44$ & 0.37 & $0.28-0.48$ & 0.33 & $0.26-0.39$ & 0.37 & $0.28-0.49$ & 0.33 & $0.25-0.41$ & $0.38^{*}$ & $0.30-0.52$ \\
\hline TAG $(\mathrm{mmol} / \mathrm{l})$ & 1.3 & $1.0-1.9$ & 1.0 & $0.8-1.5$ & 1.3 & $1 \cdot 0-1 \cdot 8$ & $1 \cdot 2$ & $0.8-1.6$ & 1.2 & $1 \cdot 0-1 \cdot 6$ & $1 \cdot 1$ & $0 \cdot 8-1 \cdot 8$ \\
\hline Bile acids ( $\mathrm{mmol} / \mathrm{l})$ & $2 \cdot 0$ & $0.8-3.8$ & $2 \cdot 0$ & $0.9-3.0$ & & ND & & ND & 1.0 & $0.7-2.0$ & $2 \cdot 0$ & $1 \cdot 0-5 \cdot 3$ \\
\hline
\end{tabular}

ND, not determined.

*Median values were significantly different from baseline within the experimental group $(P<0.05)$. The Wilcoxon signed-rank test was used to compare change within groups over time.

$\dagger$ The Mann-Whitney $U$ test was used to compare groups. No significant differences were found between the groups for any time points.

Table 6. Systolic and diastolic blood pressure†

(Medians and interquartile ranges; $n 16$ in the placebo group and $n 17$ in the fish protein group)

\begin{tabular}{|c|c|c|c|c|c|c|c|c|c|c|c|c|}
\hline & \multicolumn{4}{|c|}{ Baseline } & \multicolumn{4}{|c|}{4 weeks } & \multicolumn{4}{|c|}{8 weeks } \\
\hline & \multicolumn{2}{|c|}{ Placebo } & \multicolumn{2}{|c|}{ Fish protein } & \multicolumn{2}{|c|}{ Placebo } & \multicolumn{2}{|c|}{ Fish protein } & \multicolumn{2}{|c|}{ Placebo } & \multicolumn{2}{|c|}{ Fish protein } \\
\hline & Median & $\begin{array}{l}\text { Interquartile } \\
\text { range }\end{array}$ & Median & $\begin{array}{l}\text { Interquartile } \\
\text { range }\end{array}$ & Median & $\begin{array}{l}\text { Interquartile } \\
\text { range }\end{array}$ & Median & $\begin{array}{l}\text { Interquartile } \\
\text { range }\end{array}$ & Median & $\begin{array}{l}\text { Interquartile } \\
\text { range }\end{array}$ & Median & $\begin{array}{l}\text { Interquartile } \\
\text { range }\end{array}$ \\
\hline $\begin{array}{l}\text { Systolic } \\
(\mathrm{mmHg})\end{array}$ & 134 & $114-152$ & 130 & $126-150$ & 135 & $121-140$ & 128 & $119-139$ & 132 & $124-151$ & 130 & $124-136$ \\
\hline $\begin{array}{l}\text { Diastolic } \\
\quad(\mathrm{mmHg})\end{array}$ & 89 & $75-97$ & 82 & $72-91$ & 83 & $78-89$ & 82 & $70-83$ & $80^{*}$ & $75-88$ & 79 & $74-86$ \\
\hline
\end{tabular}

${ }^{*}$ Median value was significantly different from baseline within the experimental group $(P<0.05)$. The Wilcoxon signed-rank test was used to compare change within groups over time.

$\dagger$ The Mann-Whitney $U$ test was used to compare groups. No significant differences were found between the groups at any time points. 
the benefits observed on glucose tolerance are mainly postprandial. It should be noted that the increase in HbA1c, even though statistically significant, was only marginal.

The mechanisms by which codfish proteins improve glucose tolerance are unclear. The effects observed might be due to the amino acids in the tablets per se, or the effects may also be due to the presence of bioactive peptides that were either present in the fish protein or were released during digestion. Several studies comparing fish protein to protein from other sources explain the differences seen in insulin secretion and sensitivity as a consequence of different amino acid compositions ${ }^{(10,11,25,26)}$. Research on the stimulating effect of individual amino acids on the insulin sensitivity and secretion has mainly been conducted in acute-effect studies, and little is known about the longer-term effects of ingestion of specific amino acids. However, Ouellet et al. ${ }^{(11)}$ found that intake of cod fillet for 4 weeks improved insulin sensitivity in insulin-resistant subjects and suggested that the effects of intake of cod fillet may be caused by the amino acid composition of the cod protein acting on the insulin signalling pathway. Also Lavigne et al. ${ }^{(10)}$ reported improved fasting glucose tolerance and peripheral insulin sensitivity in rats after cod protein feeding over time, and stated that the mechanisms behind these effects are still unclear.

The cod protein used in our study contained moderate amounts of branched-chained amino acids, i.e. leucine, isoleuceine and valine, which have been suggested to affect insulin secretion. Leucine is regarded as one of the most potent amino acids in the stimulation of insulin secretion, and is able to stimulate insulin secretion by pancreas in vitro even in the absence of glucose ${ }^{(27,28)}$. Supplementation with branchedchained amino acids daily for $90 \mathrm{~d}$ improved insulin resistance in male patients with chronic viral liver disease ${ }^{(29)}$; and others have shown that leucine and isoleucine improve blood glucose clearance and uptake in skeletal muscles in acuteresponse studies ${ }^{(30,31)}$. Thus, branched-chained amino acids may therefore be important in the metabolic regulation of glucose homeostasis. Our cod protein also contained other amino acids and amino acid metabolites that may have affected the insulin sensitivity or secretion. This includes arginine, which is shown to increase peripheral and hepatic insulin sensitivity in patients with type 2 diabetes ${ }^{(32)}$, and taurine, which improves insulin sensitivity in rat models of insulin resistance $^{(33)}$ and type 2 diabetes ${ }^{(34)}$. Thus, the improved glucose tolerance observed after fish protein supplementation may be due to the amino acid composition of the protein.

Anti-inflammatory effects after intake of cod fillets are reported, with a reduction in serum CRP levels in humans ${ }^{(35)}$. However, we did not observe significant changes in CRP levels at any time points after intake of fish protein, which was expected since all participants had low CRP levels at baseline.

It was of interest to investigate whether the intake of fish protein would affect blood pressure and lipid homeostasis, as fish consumption is associated with a reduced risk of $\mathrm{CHD}^{(36)}$. Fish protein has been shown to beneficially affect blood pressure in rats ${ }^{(16)}$. However, in the present study, we found no changes in systolic or diastolic blood pressure 
after intake of fish protein, which is in line with findings in humans in the SEAFOODplus YOUNG study after intake of cod fillet ${ }^{(37)}$. However, a marginal reduction of diastolic blood pressure was observed in the placebo group $(P=0.049)$, which may be a chance finding. Intake of fish protein markedly decreased the LDL-cholesterol level and subsequently led to an increased HDL:LDL ratio over time, which is in line with findings in both rats and humans ${ }^{(12-15,17)}$, without affecting serum levels of total cholesterol and bile acids.

Fish protein supplementation resulted in increased percentage of body muscle and decreased percentage of body fat after 4 weeks, concomitant with increased body weight. Although these effects were only seen in the first 4 weeks of the study, these findings are of interest in the context that the fish protein supplement was taken without energy restriction or other changes in the participants' diets during the study period. Thus, fish protein may have a potential as bioactive food for the regulation of body fat and muscle for both agerelated sarcopenia and obese patients.

It is well known that a high dietary intake of proteins may lead to weight reduction through reduced appetite and reduced intake of energy in the short term ${ }^{(8,9)}$. In the present study, the median intake of proteins for both experimental groups combined was 82 (interquartile range 67-99) g/d at baseline, and thus an additional protein intake of 3 or $6 \mathrm{~g}$ will add little to the total daily intake of protein and energy in the fish protein group. However, no changes were seen in the intake of energy or macronutrients or in physical activity in the placebo and fish protein groups, and therefore the observed effects in the present study by fish protein intake can probably not be explained by changes in appetite, food or energy intake, or energy expenditure.

The present study has some limitations. The subjects who participated in this study were recruited through adverts in the newspaper, which may have resulted in study subjects who are more motivated to weight loss and lifestyle changes than the general obese population. The participants in this study did not get any counselling regarding eating and physical activity, but they were instructed to keep to their regular habits. Participation in a study and social desirability in relation to eating right might influence the actual dietary intake ${ }^{(38)}$; however, based on food registration, this was not the case in the present study. The small sample size increases the possibility that a clinically relevant but statistically nonsignificant result may be due to insufficient power. Another aspect of the statistical methods used is that many analyses were conducted on the same data sample. Repeated analyses on the same data increase the possibility of a type 1 error, and this involves rejecting a null hypothesis when it actually is true. This may falsely lead to the conclusion that there is difference within groups when the significant result obtained actually has occurred by chance. Many of the observed statistically significant effects were small, and the effects should be replicated in larger future trials in order to be interpreted as valid for the intervention and group of participants investigated in the present study.

In conclusion, this study shows that a daily consumption of 3-6g fish protein supplement without changing the dietary regimen and lifestyle may be sufficient to decrease LDLcholesterol and improve glucose tolerance and body composition in overweight adults, but did not affect blood pressure, HDL-cholesterol, bile acids, TAG or CRP. Further studies on the health effects of fish protein and lean fish are needed on larger cohorts and for longer time spans, especially concerning the implementation of fish protein or lean fish in normal diets, as well as tailor-made diets for individuals with impaired glucose tolerance and/or hyperlipidaemia.

\section{Acknowledgements}

L. A. V., O. K. N., E. L., E. R. and O. A. G. designed the present study. O. K. N. and E. L. obtained funding and provided administrative, technical and material support. L. A. V., O. A. G. and O. K. N. analysed and interpreted the data. L. A. V. and O. A. G. drafted the manuscript; and all authors critically reviewed the manuscript. This work was funded by the Western Norway Regional Health Authority, Haukeland University Hospital, the University of Bergen, the Mohn Research Foundation, the Department of Heart Disease and the Bergen Medical Research Foundation. E. L. is managing director of Science in Nutrition Ltd/NuF. All the other authors have no conflict of interest.

\section{References}

1. World Health Organization (2000) Obesity: preventing and managing the global epidemic. Report of a WHO consultation. World Health Organ Tech Rep Ser 894, i-xii, 1-253.

2. Carey DG, Jenkins AB, Campbell LV, et al. (1996) Abdominal fat and insulin resistance in normal and overweight women: direct measurements reveal a strong relationship in subjects at both low and high risk of NIDDM. Diabetes 45, 633-638.

3. Hubert HB, Feinleib M, McNamara PM, et al. (1983) Obesity as an independent risk factor for cardiovascular disease: a 26-year follow-up of participants in the Framingham Heart Study. Circulation 67, 968-977.

4. Insull W Jr (2009) The pathology of atherosclerosis: plaque development and plaque responses to medical treatment. Am J Med 122, S3-S14.

5. Sjostrom CD, Lystig $\mathrm{T} \&$ Lindroos AK (2011) Impact of weight change, secular trends and ageing on cardiovascular risk factors: 10-year experiences from the SOS study. Int J Obes (Lond) 35, 1413-1420.

6. Larsen TM, Dalskov SM, van Baak M, et al. (2010) Diets with high or low protein content and glycemic index for weightloss maintenance. N Engl J Med 363, 2102-2113.

7. Norwegian Directorate of Health (2010) Kostråd for å fremme folkehelsen og forebygge kroniske sykdommer i Norge - Metodologi og vitenskapelig kunnskapsgrunnlag (Dietary advice for promoting public health and prevent chronic diseases in Norway - methodology and scientific knowledge).

8. Promintzer M \& Krebs M (2006) Effects of dietary protein on glucose homeostasis. Curr Opin Clin Nutr Metab Care 9 , 463-468.

9. Tremblay F, Lavigne C, Jacques H, et al. (2007) Role of dietary proteins and amino acids in the pathogenesis of insulin resistance. Annu Rev Nutr 27, 293-310.

10. Lavigne C, Marette A \& Jacques H (2000) Cod and soy proteins compared with casein improve glucose tolerance 
and insulin sensitivity in rats. Am J Physiol Endocrinol Metab 278, E491-E500.

11. Ouellet V, Marois J, Weisnagel SJ, et al. (2007) Dietary cod protein improves insulin sensitivity in insulin-resistant men and women: a randomized controlled trial. Diabetes Care 30, 2816-2821.

12. Shukla A, Bettzieche A, Hirche F, et al. (2006) Dietary fish protein alters blood lipid concentrations and hepatic genes involved in cholesterol homeostasis in the rat model. Br J Nutr 96, 674-682.

13. Zhang X \& Beynen AC (1993) Influence of dietary fish proteins on plasma and liver cholesterol concentrations in rats. Br J Nutr 69, 767-777.

14. Iritani N, Narita R, Fujita T, et al. (1985) Effects of dietary fish protein, soybean protein and casein on cholesterol turnover in rats. J Nutr Sci Vitaminol (Tokyo) 31, 385-392.

15. Hosomi R, Fukunaga K, Arai H, et al. (2009) Effects of dietary fish protein on serum and liver lipid concentrations in rats and the expression of hepatic genes involved in lipid metabolism. J Agric Food Chem 57, 9256-9262.

16. Ait-Yahia D, Madani S, Savelli JL, et al. (2003) Dietary fish protein lowers blood pressure and alters tissue polyunsaturated fatty acid composition in spontaneously hypertensive rats. Nutrition 19, 342-346.

17. Gunnarsdottir I, Tomasson H, Kiely M, et al. (2008) Inclusion of fish or fish oil in weight-loss diets for young adults: effects on blood lipids. Int J Obes (Lond) 32, 1105-1112.

18. Benton MJ, Swan PD, Schlairet MC, et al. (2011) Comparison of body composition measurement with whole body multifrequency bioelectrical impedance and air displacement plethysmography in healthy middle-aged women. Health Care Women Int 32, 1068-1078.

19. Gibson AL, Holmes JC, Desautels RL, et al. (2008) Ability of new octapolar bioimpedance spectroscopy analyzers to predict 4-component-model percentage body fat in Hispanic, black, and white adults. Am J Clin Nutr 87, 332-338.

20. Matthews JN, Altman DG, Campbell MJ, et al. (1990) Analysis of serial measurements in medical research. BMJ 300, 230-235.

21. Matthews DR, Hosker JP, Rudenski AS, et al. (1985) Homeostasis model assessment: insulin resistance and beta-cell function from fasting plasma glucose and insulin concentrations in man. Diabetologia 28, 412-419.

22. Cohen SA \& Michaud DP (1993) Synthesis of a fluorescent derivatizing reagent, 6-aminoquinolyl- $N$-hydroxysuccinimidyl carbamate, and its application for the analysis of hydrolysate amino acids via high-performance liquid chromatography. Anal Biochem 211, 279-287.

23. Horwitz DL, Starr JI, Mako ME, et al. (1975) Proinsulin, insulin, and C-peptide concentrations in human portal and peripheral blood. J Clin Invest 55, 1278-1283.

24. Matsuda M \& DeFronzo RA (1999) Insulin sensitivity indices obtained from oral glucose tolerance testing: comparison with the euglycemic insulin clamp. Diabetes Care 22, 1462-1470.

25. Lavigne C, Tremblay F, Asselin G, et al. (2001) Prevention of skeletal muscle insulin resistance by dietary cod protein in high fat-fed rats. Am J Physiol Endocrinol Metab 281, E62-E71.

26. von Post-Skagegard M, Vessby B \& Karlstrom B (2006) Glucose and insulin responses in healthy women after intake of composite meals containing cod-, milk-, and soy protein. Eur J Clin Nutr 60, 949-954.

27. Milner RD (1969) Stimulation of insulin secretion in vitro by essential aminoacids. Lancet i, 1075-1076.

28. Andersson A, Hoiriis-Nielsen J \& Borg LA (1977) Effects of L-leucine on the insulin production, oxidative metabolism and mitochondrial ultrastructure of isolated mouse pancreatic islets in tissue culture. Diabetologia 13, 59-69.

29. Kawaguchi T, Nagao Y, Matsuoka H, et al. (2008) Branchedchain amino acid-enriched supplementation improves insulin resistance in patients with chronic liver disease. Int J Mol Med 22, 105-112.

30. Doi M, Yamaoka I, Nakayama M, et al. (2007) Hypoglycemic effect of isoleucine involves increased muscle glucose uptake and whole body glucose oxidation and decreased hepatic gluconeogenesis. Am J Physiol Endocrinol Metab 292, E1683-E1693.

31. Kalogeropoulou D, Lafave L, Schweim K, et al. (2008) Leucine, when ingested with glucose, synergistically stimulates insulin secretion and lowers blood glucose. Metabolism 57, $1747-1752$.

32. Piatti PM, Monti LD, Valsecchi G, et al. (2001) Long-term oral L-arginine administration improves peripheral and hepatic insulin sensitivity in type 2 diabetic patients. Diabetes Care 24, 875-880.

33. Nandhini AT, Thirunavukkarasu V \& Anuradha CV (2005) Taurine modifies insulin signaling enzymes in the fructosefed insulin resistant rats. Diabetes Metab 31, 337-344.

34. Nakaya Y, Minami A, Harada N, et al. (2000) Taurine improves insulin sensitivity in the Otsuka Long-Evans Tokushima Fatty rat, a model of spontaneous type 2 diabetes. Am J Clin Nutr 71, 54-58.

35. Ouellet V, Weisnagel SJ, Marois J, et al. (2008) Dietary cod protein reduces plasma C-reactive protein in insulin-resistant men and women. J Nutr 138, 2386-2391.

36. Konig A, Bouzan C, Cohen JT, et al. (2005) A quantitative analysis of fish consumption and coronary heart disease mortality. Am J Prev Med 29, 335-346.

37. Ramel A, Martinez JA, Kiely M, et al. (2010) Moderate consumption of fatty fish reduces diastolic blood pressure in overweight and obese European young adults during energy restriction. Nutrition 26, 168-174.

38. Lissner L, Heitmann BL \& Bengtsson C (2000) Population studies of diet and obesity. Br J Nutr 83, Suppl. 1, S21-S24. 